\title{
Nck-Associated Protein 1
}

National Cancer Institute

\section{Source}

National Cancer Institute. Nck-Associated Protein 1. NCI Thesaurus. Code C138142.

Nck-associated protein 1 (1128 aa, 129 kDa) is encoded by the human NCKAP1 gene.

This protein is involved in both cell morphology and endocytosis. 